\title{
Pemberian Lidah Buaya, Daun Sirih, dan Concentrated Mineral Drops (CMD) Dalam Mempertahankan Kesegaran Bunga Sedap Malam (Polianthes tuberosa L.)
}

\section{Graining Grain, Leaf and Concentrated Mineral Drops (CMD) In Maintaining Interest Interests Of Night Layer (Polianthes tuberosa L.)}

\author{
Mashan Hasanatien, Ahmad Rafiqi Tantawi \& Gusmeizal \\ Fakultas Pertanian, Universitas Medan Area, Indonesia \\ *Corresponding author: E-mail: mashanumafp@gmail.com
}

\begin{abstract}
Abstrak
Percobaan ini dilakukan untuk mencari perlakuan larutan peraga (holding) yang mampu mempertahankan kesegaran bunga sedap malam selama peragaan. Penelitian ini dilakukan di Laboratorium Fakultas Pertanian, Universitas Medan Area. Bahan yang digunakan adalah bunga sedap malam yang memiliki bunga mekar 1 - 2 kuntum, ekstrak lidah buaya, ekstrak daun sirih, Concentrated Mineral Drops (CMD), serta setiap perlakuan diberi gula sebagai cadangan energi untuk bunga sedap malam selama peragaan dan asam sitrat yang berfungsi menurunkan keasaman $(\mathrm{pH})$ larutan peraga (holding). Alat yang digunaka dalam penelitian ini adalah pisau, blender, ember, botol plastik, timbangan, penggaris panjang, gelas ukur, dan spatula. Rancangan yang digunakan yaitu RAL non faktorial dengan 9 taraf perlakuan larutan peraga. setiap perlakuan diulang sebanyak 3 ulangan. Hasil percobaan dianalisis dengan analisis ragam dan uji kontras ortogonal. Hasil penelitian menunjukkan bahwa larutan peraga yang mendapat perlakuan dari ekstrak lidah buaya, ekstrak daun sirih, CMD, gula, asam sitrat mampu mempertahankan kesegaran bunga sedap malam selama 5 hari. Larutan perlakuan dengan menggunakan ekstrak sirih lebih ekonomis dibandingkan dengan perlakuan lainnya karena pada hari ke-6 peragaan kondisi fisik bunga masih dalam kondisi cukup baik.

Kata Kunci: Ekstrak, Larutan, Bunga Sedap Malam
\end{abstract}

\begin{abstract}
This experiment was carried out to find the treatment of the holding solution which was able to maintain the freshness of the night flower during the demonstration. This research was conducted at the Laboratory of Faculty of Agriculture, University of Medan Area. The ingredients used are the night flower having flower 1 - 2 flower, aloe vera extract, betel leaf extract, Concentrated Mineral Drops (CMD), and each treatment is given sugar as energy reserve for the night flower during demonstration and citric acid that function reduce the acidity $(\mathrm{pH})$ of the auxiliary solution (holding). Tools used in this research are knives, blenders, buckets, plastic bottles, scales, long ruler, measuring cups, and spatulas. The design used was non factorial RAL with 9 levels of treatment of visual aids. each treatment was repeated as many as 3 replications. The experimental results were analyzed by various analysis and orthogonal contrast test. The result of the research showed that the solution of the treatment of aloe vera extract, betel leaf extract, $C M D$, sugar, citric acid was able to maintain the freshness of the night flower for 5 days. The treatment solution using betel extract is more economical compared to other treatment because on the 6th day the physical condition of the flower is still in good condition.
\end{abstract}

Keywords: Extracts, Solutions, Nightflowers

How to Cite: Hasanatien M., Ahmad R.T. \& Gusmeizal, (2018), Pemberian Lidah Buaya, Daun Sirih, dan Concentrated Mineral Drops (CMD) Dalam Mempertahankan Kesegaran Bunga Sedap Malam (Polianthes tuberosa L.), Agrotekma, 2 (2): 107-120. 


\section{PENDAHULUAN}

Sedap Malam termasuk tanaman hias yang populer karena bentuk bunganya yang indah dan harum, sehingga disukai oleh masyarakat pedesaan maupun perkotaan. Aroma bunga sedap malam ternyata mampu mengobati stres, sehingga membantu dalam proses penyembuhan beberapa penyakit dengan menggunakan bunga sedap malam sebagai aroma terapi. Selain digunakan sebagai bunga potong, sedap malam banyak dimanfaatkan sebagai bunga tabur dan bahan baku industri minyak atsiri (Suyanti, 2002).

Peningkatan produksi bunga sedap malam pada tahun 2006 mencapai 30.374.000 tangkai menduduki urutan ketiga setelah bunga mawar dan Krisan (Badan Pusat Statistik, 2008). Mutu bunga dianggap baik apabila sepertiga bagian kuntum bunga dalam setiap malainya mekar. Namun, bunga dengan tingkat kemekaran tersebut tidak tahan selama pengangkutan karena bunga yang telah mekar, sepal akan mengalami kerapuhan. Untuk pengangkutan jarak jauh, panen yang tepat adalah apabila 1-2 kuntum bunga dalam setiap malainya telah mekar. Bunga yang masih kuncup saat dipanen akan mekar selama dalam peragaan. Bunga yang telah mekar akan mengalami kelayuan dalam 2-3 hari, sehingga akan mengurangi keindahan bunga (Suyanti, 2002).

Bunga sedap malam yang telah dipotong tetap menjalankan aktivitas metabolisme hidupnya. Supaya kualitas bunga tetap prima hingga sampai ke tangan konsumen, bunga perlu diberi nutrisi dan bahan pengawet, baik ke dalam larutan perendam maupun larutan peraga. Nutrisi sangat dibutuhkan oleh bunga untuk melakukan aktivitas metabolisme hidupnya, mempertahan-kan warna bunga, menghambat kelayuan, meningkatkan ukuran bunga mekar, dan menambah kemekaran bunga. Nutrisi yang ditambahkan dapat berupa sukrosa sebagai sumber karbohidrat dan dikombinasikan dengan germisida, zat pengatur tumbuh, mineral dan zat penghambat etilen (Nowak dan Rudnicki 1990 dalam Suyanti 2002).

Concentarated Mineral Drops (CMD) merupakan konsentrat mineral yang berasal dari Danau Great Salt Utah yang telah dibuang 95\% garamnya. CMD mengandung keseimbangan mineral berionik sempurna yang ditemukan secara alami di air laut. CMD terdiri dari mineral makro (magnesium, kalsium, pottasium, klorida, sulfur) dan mineral mikro (kromium, iodin, mangan, selenium dan zink) yang sangat dibutuhkan oleh makhluk hidup, khususnya membantu 
kelangsungan pertumbuhan pada tanaman (Revell Indonesia, 2008).

Ekstrak lidah buaya dan ekstrak sirih mampu menekan pertumbuhan bakteri (bakterisida). Sehingga dibutuhkan penambahan bakterisida untuk menekan pertumbuhan bakteri pada larutan peraga (holding) selama peragaan yang diketahui bahwa pertumbuhan bakteri dapat meningkat-kan laju etilen sehingga mempercepat proses kelayuan (senescens) pada bunga potong. Disamping itu kedua bahan tersebut mudah diperoleh dan ramah terhadap lingkungan.

Mineral merupakan salah satu zat yang dapat ditambahkan sebagai nutrisi pada larutan peraga untuk mempertahankan kesegaran bunga potong selama peragaan. Memanfaatkan ekstrak lidah buaya dan ekstrak sirih sebagai bakterisida alami dalam larutan peraga (holding) untuk memperpanjang masa kesegaran bunga sedap malam. Memanfaatkan Concentrated Mineral Drops (CMD) sebagai sumber mineral yang dapat ditambahkan (additif) dalam larutan peraga untuk memperpanjang masa kesegaran bunga sedap malam. Kegunaan Penelitian yang dilakukan yaitu Untuk mengetahui bahwa pemberian ekstrak lidah buaya, ekstrak sirih dan Concentrated Mineral Drops (CMD) dapat digunakan sebagai additif pada larutan peraga (holding) alternatif yang aman bagi lingkungan.

\section{METODE PENELITIAN}

Bahan-bahan yang digunakan dalam penelitian ini adalah sedap malam $(P$. tuberosa L.) yang diperoleh dari Pajak Sore Padang Bulan, Medan. Bahan lainnya antara lain aquades, gula pasir, asam sitrat, ekstrak sirih, ekstrak lidah buaya dan Concentrated Mineral Drops (CMD). Alatalat yang digunakan antara lain pisau atau cutter, blender, ember, botol plastik, timbangan, penggaris panjang, gelas ukur, spatula, lak, dan lain-lain. Semua alat dalam keadaan bersih.

Penelitian ini menggunakan Rancangan Acak Lengkap (RAL) non faktorial dengan 9 taraf perlakuan larutan peraga (holding) yaitu $\mathrm{HO}=$ Kontrol dengan aquades, $\mathrm{H} 1$ = Ekstrak daun sirih $250 \mathrm{~g} / \mathrm{l}+$ gula pasir $100 \mathrm{~g} / \mathrm{l}+$ asam sitrat 0,15 g/l, H2 = Ekstrak lidah buaya $25 \mathrm{ml} / \mathrm{l}$ + gula pasir $100 \mathrm{~g} / \mathrm{l}+$ asam sitrat 0,15 g/l, H3 = Ekstrak daun sirih $250 \mathrm{~g} / \mathrm{l}+$ gula pasir $100 \mathrm{~g} / \mathrm{l}+$ asam sitrat 0,15 g/l + CMD 5 tetes, $\mathrm{H} 4=$ Ekstrak daun sirih $250 \mathrm{~g} / \mathrm{l}+$ gula pasir $100 \mathrm{~g} / \mathrm{l}+$ asam sitrat $0,15 \mathrm{~g} / \mathrm{l}+$ CMD 10 tetes, $\mathrm{H} 5=$ Ekstrak daun sirih 250 $\mathrm{g} / \mathrm{l}+$ gula pasir $100 \mathrm{~g} / \mathrm{l}+$ asam sitrat 0,15 g/l + CMD 15 tetes, $\mathrm{H6}=$ Ekstrak daun sirih $250 \mathrm{~g} / \mathrm{l}+$ ekstrak lidah buaya $25 \mathrm{ml} / \mathrm{l}+$ gula pasir $100 \mathrm{~g} / \mathrm{l}+$ asam sitrat $0,15 \mathrm{~g} / \mathrm{l}+$ CMD 5 tetes, $\mathrm{H7}=$ Ekstrak daun sirih 250 
$\mathrm{g} / \mathrm{l}+$ ekstrak lidah buaya $25 \mathrm{ml} / \mathrm{l}+$ gula pasir $100 \mathrm{~g} / \mathrm{l}+$ asam sitrat $0,15 \mathrm{~g} / \mathrm{l}+\mathrm{CMD}$ 10 tetes, $\mathrm{H} 8=$ Ekstrak daun sirih $250 \mathrm{~g} / \mathrm{l}+$ ekstrak lidah buaya $25 \mathrm{ml} / \mathrm{l}+$ gula pasir $100 \mathrm{~g} / \mathrm{l}+$ asam sitrat 0,15 g/l + CMD 15 tetes.

Dengan Model Linier Additifnya sebagai berikut :

$$
\mathrm{Y}_{\mathrm{ij}}=\mu_{0}+\tau_{\mathrm{j}}+\epsilon_{\mathrm{ij}}
$$

\section{Keterangan :}

$\mathrm{Y}_{\mathrm{ij}}=$ Hasil pengamatan plot percobaan yang mendapat perlakuan taraf ke-j, dan di tempatkan di ulangan ke-i

$\mu_{0}=$ Pengaruh rata-rata umum (nilai tengah)

$t_{j}=$ Pengaruh perlakuan taraf ke-j

$\sum_{\mathrm{ij}}=$ Pengaruh galat percobaan dari setiap plot percobaan yang mendapat perlakuan faktor taraf ke-j dan ditempatkan di ulangan ke-i.

Setiap perlakuan diulang sebanyak 3 ulangan, sehingga total perlakuan sebanyak 27 perlakuan. Tiap perlakuan terdiri dari 3 tangkai bunga sedap malam, maka jumlah tangkai bunga perlakuan sebanyak 81 tangkai.

Pelaksanaan penelitian ini terdiri dari beberapa tahap, yaitu Persiapan alat dan bahan (1) Bunga sedap malam disortasi dengan memilih tangkai yang berbunga 12 kuntum, lalu daun bunga di buang. Tangkai bunga disamakan panjangnya \pm 40 cm dari bunga terbawah dan ujung tangkai dipotong menyerong. (2) Pembuatan larutan peraga (holding). Pembuatan larutan peraga dilaksanakan 1-3 hari sebelum perlakuan. Larutan peraga dengan asam sitrat $0,15 \mathrm{~g}$, gula pasir $100 \mathrm{~g}$, dilarutkan dengan bahan pelarut aquades sebanyak 1 liter. Kemudian ditambahkan masing-masing ekstrak daun sirih $250 \mathrm{~g}$, ekstrak lidah buaya $25 \mathrm{ml}$, dan CMD tiga konsentrasi (5, 10, dan 15 tetes.) Masingmasing larutan peraga dimasukkan ke dalam botol plastik sebanyak $200 \mathrm{ml}$ serta aquades digunakan sebagai kontrol. (3) Peragaan dalam larutan peraga (holding). Bunga sedap malam yang telah disiapkan dimasukkan ke dalam larutan peraga pada setiap perlakuan. Dalam setiap botol plastik digunakan $200 \mathrm{ml}$ larutan peraga lalu mulut botol ditutup dengan menggunakan lak. Setiap perlakuan peraga berisi tiga tangkai bunga dengan tiga ulangan dan diletakkan pada ruangan bersuhu kamar.

Bunga sedap malam diambil dari Pajak Sore Padang Bulan pada saat malam hari dan merupakan tipe bunga tunggal yang memiliki ciri khas pada ujung kuntum bunga berwarna agak kemerahkemerahan. Lalu dilakukan pemotongan tangkai sesuai dengan ukuran yang dibutuhkan (+ $40 \mathrm{~cm})$ dan direndam sementara dengan aquades untuk 
mempertahankan kesegaran bunga selama perjalanan menuju Laboratorium HPT. Selama pengamatan, kondisi cuaca setiap hari hujan sehingga kondisi suhu ruangan relatif sejuk dan selama penyimpanan ruangan laboratorium dalam kondisi gelap.

Perendaman bunga sedap malam pada larutan peraga dilakukan dengan tempo cepat agar tidak terjadi perbedaan waktu rendam yang terlampau jauh. Tinggi volume larutan peraga adalah sekitar $6 \mathrm{~cm}$.

Masa Penyimpanan sedap malam dilakukan hingga 6 hari. Pada hari ke-3 pemajangan didapati semut disekitar area plot penelitian bahkan ada beberapa botol perlakuan termasuki semut sehingga diatasi dengan pemberian kapur anti semut pada area plot penelitian tersebut untuk mengantisipasi kontaminasi larutan peraga oleh bakteri yang terbawa pada semut.

Selama proses penyimpanan, satu larutan peraga perlakuan ekstrak lidah buaya (H23) terkontaminasi oleh semut dan cendawan disebabkan oleh kondisi lak pada mulut botol agak sedikit terbuka sehingga semut dapat masuk dan cendawan dapat berkembang biak. Kontaminasi bakteri atau cendawan akan menyebabkan berkurangnya penyerapan air karena tersumbatnya sistem vaskular tanaman (Whealy 1992 dalam Sukma, Dewi dan Gigin Mardiansyah. 2007).

\section{Parameter yang diamati adalah: Jumlah} kuntum bunga mekar

Pengamatan dilakukan setiap hari dengan menghitung jumlah bunga mekar sebagai kriterianya adalah apabila sepal bunga $50 \%$ telah membuka.

Persentase kuntum bunga layu

Tingkat kelayuan bunga dihitung dengan melihat persentase kuntum bunga yang layu. Rumus yang digunakan:

Persentase $=$

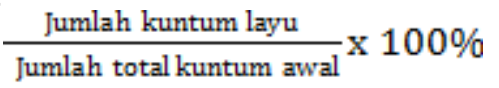

Pengamatan dilakukan setiap hari dengan kriteria sepal bunga mengkerut, warna kecoklatan, dan rontok. Vase life atau umur peragaan (ketahanan simpan), yaitu umur ketahanan bunga dalam keadaan segar yang dihitung sejak bunga dipanen hingga 50\% jumlah kuntum bunga menjadi layu atau gugur.

\section{Volume Larutan Peraga (Holding) Yang Terserap}

Banyaknya larutan yang terserap berbanding lurus dengan tingkat metabolisme bunga potong tersebut. Semakin banyak jumlah sukrosa dan air, serta pengawet yang diserap maka semakin tinggi tingkat penyerapan dan kemekaran bunga yang sekaligus akan memperpanjang umur peragaan (vase life). Total larutan yang terserap dihitung melalui selisih volume larutan awal 
dengan volume larutan saat vase life (umur peragaan) berakhir.

\section{HASIL DAN PEMBAHASAN \\ Persentase Kuntum Bunga Layu}

Hasil analisis ragam uji kontras ortogonal menunjukkan bahwa perlakuan berbagai larutan peraga tidak berpengaruh secara nyata terhadap persentase kuntum bunga layu selama peragaan kecuali pada hari ke-5 peragaan menunjukkan bahwa penggunaan aquades memiliki persentase kuntum bunga layu yang tinggi berbeda nyata terhadap perlakuan lainnya sebanyak 28.18\% (Tabel 3). Hal ini disebabkan bunga sedap malam tidak mendapatkan sumber energi yaitu berupa gula dan antibakteri berupa asam sitrat, ekstrak sirih, dan ekstrak lidah buaya sehingga diduga aquades terkontaminasi oleh bakteri yang terbawa pada tangkai bunga. Diketahui bahwa keberadaan bakteri dapat meningkatkan laju etilen yang mampu mempercepat proses kelayuan pada bunga potong. Sesuai dengan laporan hasil penelitian yang telah dilakukan oleh Kurniawan, dkk (2008) bahwa air PDAM yang telah didisinfektan digunakan sebagai larutan perendam pada bunga anggrek Dendrobium sonia memiliki kerapatan koloni bakteri lebih tinggi dibandingkan yang mendapat perlakuan ekstrak sirih yaitu sebanyak $4.7 \times 10^{4}$ koloni/ml. Sebagian besar kuntum bunga yang layu adalah kuntum bunga yang belum mekar yaitu kuntum bunga yang terdapat pada bagian ujung tangkai bunga. Proses pelayuan kuntum bunga yang belum mekar lebih cepat dibandingkan dengan proses pelayuan pada kuntum bunga yang telah mekar. Hal ini diduga karena larutan peraga tidak terserap oleh tangkai bunga atau tidak mencapai kuntum bunga paling ujung sehingga tidak mendapatkan energi untuk proses pemekaran bunga.

Tabel 3. Persentase Kuntum Bunga Layu Sedap Malam Pada 3 - 6 HP Pada Berbagai Larutan Peraga

\begin{tabular}{|c|c|c|c|c|}
\hline \multirow{2}{*}{ Perlakuan } & \multicolumn{4}{|c|}{ Kuntum Bunga Layu (\%) } \\
\hline & $3 \mathrm{HP}$ & $4 \mathrm{HP}$ & $5 \mathrm{HP}$ & $6 \mathrm{HP}$ \\
\hline $\mathrm{HO}$ & $1.39 \mathrm{tn}$ & $4.48 \mathrm{tn}$ & $28.18 *$ & $64.94 \mathrm{tn}$ \\
\hline H1 & $0.81 \mathrm{tn}$ & $1.67 \mathrm{tn}$ & $13.83 \mathrm{tn}$ & $56.33 \mathrm{tn}$ \\
\hline $\mathrm{H} 2$ & $0.95 \mathrm{tn}$ & $5.82 \mathrm{tn}$ & $20.15 \mathrm{tn}$ & $56.85 \mathrm{tn}$ \\
\hline H3 & $0.00 \mathrm{th}$ & $2.56 \mathrm{tn}$ & $18.44 \mathrm{th}$ & $66.92 \mathrm{tn}$ \\
\hline $\mathrm{H} 4$ & $0.60 \mathrm{tn}$ & $2.73 \mathrm{tn}$ & $20.70 \mathrm{th}$ & $72.41 \mathrm{tn}$ \\
\hline H5 & $1.29 \mathrm{tn}$ & $4.97 \mathrm{tn}$ & $16.99 \mathrm{tn}$ & $75.45 \mathrm{tn}$ \\
\hline H6 & $0.95 \mathrm{tn}$ & $7.54 \mathrm{tn}$ & $16.45 \mathrm{tn}$ & $65.18 \mathrm{tn}$ \\
\hline $\mathrm{H} 7$ & $0.63 \mathrm{th}$ & $8.53 \mathrm{tn}$ & $12.83 \mathrm{tn}$ & $75.73 \mathrm{tn}$ \\
\hline H8 & $0.62 \mathrm{tn}$ & $5.16 \mathrm{tn}$ & $12.29 \mathrm{tn}$ & $75.10 \mathrm{tn}$ \\
\hline
\end{tabular}


Dengan demikian penggunaan penggunaan kedua jenis ekstrak yang komposisi larutan peraga mampu ditambahkan CMD (H7 dan H8) mempertahankan kesegaran bunga sedap menunjukkan persentase kelayuan lebih malam selama lima hari akan tetapi pada rendah. Namun, pada hari ke-6 peragaan hari keenam bunga telah mengalami bunga sedap malam memiliki penampilan persentase kelayuan lebih dari 50\%. fisik cukup baik dan persentase kelayuan Dilihat dari persentase kelayuan pada hari lebih rendah pada perlakuan $\mathrm{H} 1$ dari pada ke-5 peragaan penggunaan ekstrak sirih H7 danH8.

(H1) lebih ekonomis meskipun pada

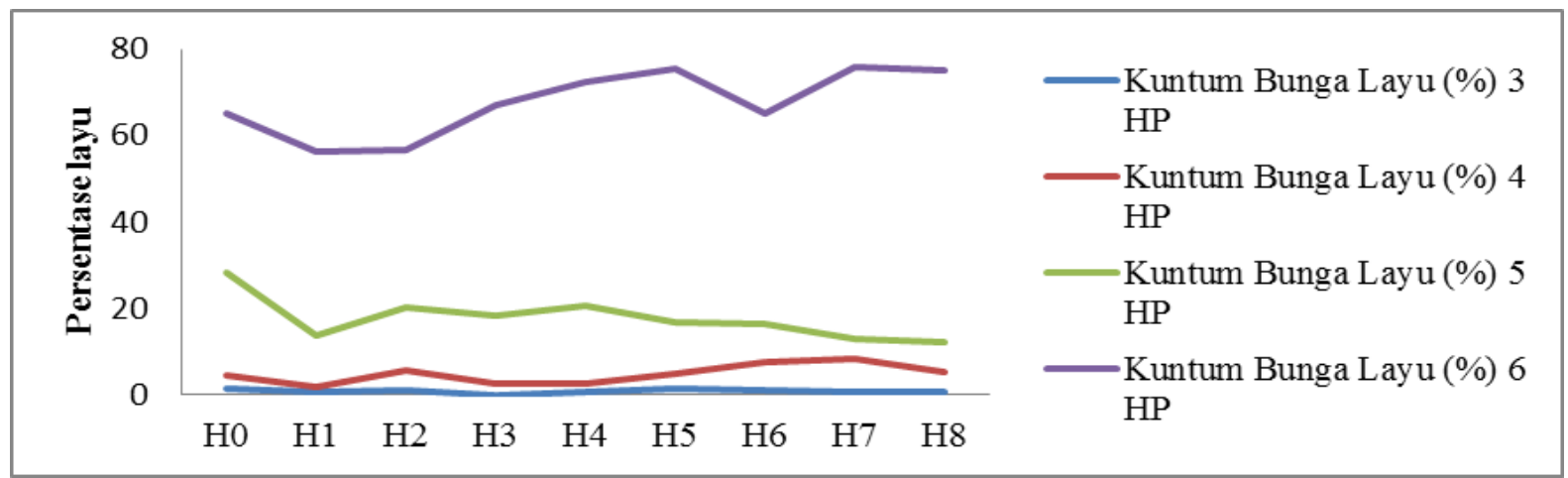

Gambar 1. Persentase Kuntum Bunga Layu Sedap Malam Pada 3 - 6 HP Pada Berbagai Larutan Peraga

Dapat dilihat pada Gambar 1. bahwa larutan peraga yang ditambahkan tetesan CMD cenderung menunjukkan tren yang naik atau mampu memperbesar tingkat kelayuan kuntum bunga sedap malam pada hari ke- 6 peragaan. Hal ini diduga karena keberadaan sodium dan fluorida yang terkandung dalam CMD. Kandungan sodium pada larutan perendam dapat bersifat toksik pada bunga anyelir dan bunga mawar sehingga daun bunga terlihat seperti terbakar (burning). Selain itu larutan perendam yang mengandung fluorida dapat bersifat toksik terhadap bunga gerbera, gladiol, dan mawar. Kandungan fluorida 1 ppm pada larutan perendam mampu merusak penampilan pada bunga potong tersebut

\section{Volume Larutan Peraga (holding) yang Terserap}

Volume awal larutan awal dalam botol peraga adalah $200 \mathrm{ml}$. Volume larutan pada akhir pengamatan mengalami pengurangan dan dihitung sebagai volume larutan terserap. Botol peraga yang digunakan sebagai wadah larutan peraga ditutup rapat dengan lak agar dapat mengurangi terjadinya penguapan (evaporasi) larutan peraga dan menghindari kontaminasi semut serta cendawan dari udara bebas dalam 
laboratorium. Volume larutan yang terserap dapat dipengaruhi salah satunya oleh keberadaan mikroba yang menyerang tangkai bunga selama proses penyimpanan. Mikroba yang tumbuh dan berkembang dalam larutan peraga dapat berbahaya bagi bunga potong karena dapat mengganggu perkembangan bunga potong dan dapat mengakibatkan tersumbatnya jaringan xilem dan ujung tangkai bunga potong tersebut (Anjum et al. 2001 dalam Sukma, dkk. 2007). Faktor lain yang dapat mempengaruhi penyerapan larutan peraga adalah keragaman pada diameter tangkai bunga dan luas permukaan serap tangkai, jumlah kuntum mekar dan jumlah kuntum keseluruhan yang beragam, serta perubahan suhu kamar. Berikut hasil analisis ragam uji kontras ortogonal volume larutan peraga yang terserap disajikan pada Tabel 4.

Hasil analisis ragam uji kontras ortogonal menunjukkan bahwa perlakuan berbagai larutan peraga sangat nyata berpengaruh terhadap volume larutan peraga yang diserap oleh bunga sedap malam selama peragaan kecuali pada perbandingan kontras antara perlakuan H7 terhadap H8 berpengaruh secara tidak nyata. Dengan artian bahwa penambahan konsentrasi CMD 10 - 15 tetes dalam 1 liter larutan peraga yang menggunakan ekstrak daun sirih dan ekstrak lidah buaya tidak berpengaruh secara nyata terhadap daya serap bunga sedap malam pada larutan peraga tersebut.

Dapat dilihat pada Tabel 4. bahwa perlakuan kontrol dengan aquades memiliki daya serap sangat nyata lebih rendah daripada yang diberi perlakuan. Dalam artian bahwa pemberian ekstrak lidah buaya, ekstrak sirih, gula, asam sitrat serta CMD mampu meningkatkan daya serap bunga sedap malam lebih baik daripada pemberian larutan peraga berupa aquades saja. Hal ini dikarenakan aquades memiliki pH netral dibandingkan dengan larutan peraga lainnya yang terdapat asam sitrat untuk menurunkan keasaman $(\mathrm{pH})$ larutan. Telah diketahui bahwa tingkat keasaman yang tinggi ( $\mathrm{pH} 3$ - 5) dapat meningkatkan penyerapan larutan oleh bunga potong (Conrado et al. 1980 dalam Tisnawati 2005).

Perbandingan kontras larutan peraga antara ekstrak daun sirih dengan ekstrak lidah buaya (H1 Vs H2) menunjukkan bahwa penggunaan ekstrak daun sirih memiliki daya serap yang sangat nyata berbeda daripada ekstrak lidah buaya. Hal ini diduga karena ekstrak lidah buaya yang berupa gel bersifat melapisi luas permukaan serap tangkai sehingga menghambat daya serap bunga sedap malam terhadap larutan peraga tersebut. 
Tabel 4. Uji Kontras Ortogonal Pengaruh Berbagai Larutan Peraga Terhadap Volume Larutan Peraga yang Terserap Pada Bunga Sedap Malam Selama Peragaan

\begin{tabular}{lccc}
\hline \multirow{2}{*}{ Kontras } & Rata-rata perlakuan (ml terserap) & 0.5 & Notasi \\
\cline { 3 - 4 } H0 Vs lainnya & 44.17 & & 0.1 \\
H0 & 51.19 & $\mathrm{~B}$ & $\mathrm{~B}$ \\
Lainnya & & $\mathrm{A}$ & $\mathrm{A}$ \\
H1 Vs H2 & & $\mathrm{A}$ \\
H1 & 48.90 & $\mathrm{~A}$ & $\mathrm{~B}$ \\
H2 & 44.17 & $\mathrm{~B}$ & \\
H1 Vs H3, H4, H5 & & & $\mathrm{D}$ \\
H1 & 48.90 & $\mathrm{D}$ & $\mathrm{C}$ \\
H3 & 50.00 & $\mathrm{C}$ & $\mathrm{A}$ \\
H4 & 57.33 & $\mathrm{~A}$ & $\mathrm{~B}$ \\
H5 & 50.67 & $\mathrm{~B}$ & \\
H2 Vs H6, H7, H8 & & & $\mathrm{C}$ \\
H2 & 44.17 & $\mathrm{C}$ & $\mathrm{A}$ \\
H6 & 57.17 & $\mathrm{~A}$ & $\mathrm{~B}$ \\
H7 & 49.17 & $\mathrm{~B}$ & $\mathrm{~B}$ \\
H8 & 52.17 & $\mathrm{~B}$ & \\
\hline
\end{tabular}

Keterangan : Angka-angka pada baris yang sama yang diikuti dengan huruf yang sama tidak berbeda nyata pada uji kontras ortogonal dengan tingkat keyakinan $95 \%$ dan $99 \%$

Pada perbandingan kontras antara Vs H6, H7, H8) menunjukkan bahwa larutan peraga yang menggunakan ekstrak perlakuan ekstrak lidah buaya (H2) daun sirih dengan penambahan 5,10, dan memiliki daya serap sangat nyata lebih 15 tetes CMD (H1 Vs H3, H4, H5) rendah daripada yang diberi perlakuan berpengaruh sangat nyata terhadap daya dengan penambahan tetesan CMD. Dari serap bunga pada larutan peraga. Hal ini ketiga perlakuan (H6, H7, H8) yang menunjukkan bahwa penamba-han CMD menunjukkan perlakuan memiliki daya mampu meningkatkan daya serap bunga serap tertinggi terdapat pada sedap malam terhadap larutan peraga dan penambahan CMD sebanyak 5 tetes dalam dari ketiga perlakuan (H3, H4, H5) 1 liter larutan peraga yaitu sebesar 57.17 tersebut menunjukkan bahwa $\mathrm{ml}$. penambahan CMD sebanyak 10 tetes dalam 1 liter larutan mampu meningkatkan daya serap bunga terhadap larutan peraga sebanyak $57.33 \mathrm{ml}$.

Disamping itu, perbandingan kontras antara larutan peraga yang menggunakan ekstrak daun sirih dan lidah buaya dengan penambahan 5, 10, dan 15 tetes CMD (H2

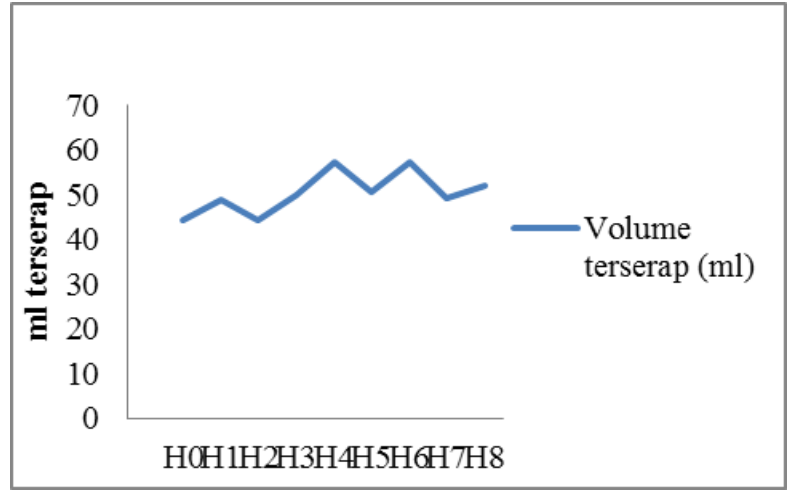

Gambar 2. Volume Larutan Peraga yang Terserap Pada Bunga Sedap Malam Selama Masa Peragaan 
Dapat dilihat pada Gambar 2. bahwa volume larutan peraga yang terserap oleh bunga sedap malam selama peragaan pada berbagai larutan peraga bersifat fluktuatif. Terlihat bahwa penambahan tetesan CMD berpengaruh terhadap daya serap bunga sedap malam terhadap larutan peraga tersebut. Semakin tinggi konsentrasi atau jumlah tetesan CMD yang diberikan ada yang menunjukkan respon sinergis maupun antagonis dalam menyerap larutan peraga. Dapat dilihat pada perlakuan $\mathrm{H} 4$ bahwa penambahan 10 tetes CMD memberikan respon sinergis sedangkan pada perlakuan H5, H7, dan H8 menunjukkan respon antagonis terhadap daya serap bunga sedap malam terhadap larutan peraga tersebut. Hal ini diduga keberadaan sodium (mampu merubah daya osmotik potensial air) dan kalium yang terdapat pada CMD. Diketahui bahwa tingginya konsentrasi kalium pada larutan mampu menghambat tanaman untuk menyerap unsur mineral lainnya (http:// www. lenntech. com/ periodic/elements/k.htm).

Sehingga keberadaan sodium dan kalium ini diduga mengurangi daya serap bunga sedap malam terhadap larutan peraga. Namun, hal ini perlu diteliti lebih lanjut karena belum ada penelitian mengenai larutan peraga dengan perlakuan penambahan unsur mineral terutama kalium.

\section{Vase life atau Umur Peragaan}

Umur peragaan atau masa kesegaran bunga sedap malam merupakan komponen utama penentu kualitas bunga potong yang dihitung sejak bunga dipanen hingga menjadi layu atau gugur.

Dalam penelitian ini untuk mempertahankan masa kesegaran bunga sedap malam digunakan larutan peraga yang mengandung air sebagai pelarut, gula sebagai cadangan makanan, asam sitrat untuk menurunkan $\mathrm{pH}$ air, bakterisida sebagai penghambat pertumbuhan bakteri yang berupa ekstrak daun sirih dan ekstrak lidah buaya, serta Concentrated Mineral Drops (CMD) sebagai sumber mineral tambahan.

Hasil penelitian menunjukkan bahwa penggunaan berbagai komposisi larutan peraga antara ekstrak daun sirih, ekstrak lidah buaya, gula, asam sitrat serta CMD jika dilihat dari persentase kelayuan (12.29\% - 20.70\%) berpengaruh nyata dalam memper-panjang masa kesegaran atau umur peragaan dibandingkan dengan peng-gunaan aquades saja (28.18\%). Keseluruhan perlakuan tersebut hanya mampu memperpanjang masa peragaan selama lima hari. Menurut pengalaman pedagang bunga di Pajak Sore Padang 
Bulan, kesegaran bunga sedap malam hanya mampu bertahan $3-4$ hari peragaan dengan penggunaan air PDAM (Komunikasi Pribadi). Namun, dari penampilan fisik bunga sedap malam pada hari ke-6 peragaan yang masih menunjukkan kondisi cukup baik adalah penggunaan larutan ekstrak daun sirih 250

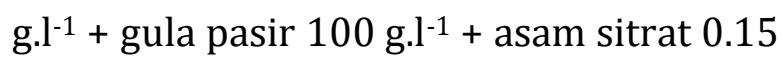
g.l-1 (H1) yang dapat dilihat pada lampiran 21. Hal ini sesuai dengan penelitian Kurniawan, dkk (2008) bahwa penggunaan ekstrak sirih dalam larutan perendam pada bunga anggrek memiliki tren yang positif dalam memperpanjang umur kesegaran bunga anggrek potong. Hal ini menunjukkan bahwa penggunaan komposisi larutan peraga diatas sangat

\section{Jumlah Kuntum Bunga Mekar}

Tabel 5. Jumlah Kuntum Bunga Mekar Sedap Malam Selama Masa Peragaan

\begin{tabular}{cccccc}
\hline \multirow{2}{*}{ Perlakuan } & \multicolumn{3}{c}{ Jumlah bunga mekar (kuntum) } & \multirow{2}{*}{ Total Perlakuan } & \multirow{2}{*}{ Rataan Perlakuan } \\
\cline { 2 - 3 } & I & II & III & & \\
\hline H0 & 11 & 11 & 19 & 41 & 13.67 \\
H1 & 7 & 12 & 17 & 36 & 12.00 \\
H2 & 13 & 13 & 16 & 42 & 14.00 \\
H3 & 10 & 18 & 21 & 49 & 16.33 \\
H4 & 7 & 15 & 15 & 37 & 12.33 \\
H5 & 13 & 22 & 15 & 50 & 16.67 \\
H6 & 22 & 19 & 14 & 55 & 18.33 \\
H7 & 21 & 12 & 15 & 48 & 16.00 \\
H8 & 10 & 19 & 9 & 38 & 12.67 \\
Total & 114 & 141 & 141 & 396 & 14.67 \\
\hline
\end{tabular}


Hasil analisis ragam uji kontras ortogonal menunjukkan bahwa perlakuan berbagai larutan peraga tidak berpengaruh secara nyata terhadap jumlah kuntum bunga mekar selama peragaan (Lampiran 2). Namun, perlakuan larutan ekstrak daun sirih 250 g.l $^{-1}+$ ekstrak lidah buaya $25 \mathrm{ml}^{-\mathrm{l}^{-1}}+$ gula pasir 100 g. $^{-1}+$ asam sitrat 0.15 g. $^{-1}+5$ tetes CMD dapat meningkatkan jumlah kuntum bunga mekar tertinggi, rata-rata 18 kuntum, diikuti penggunaan ekstrak sirih 250 g.l $\mathrm{l}^{-1}+$ gula pasir 100 g.l-1 + asam sitrat 0.15 g.l-1 +15 tetes CMD dengan jumlah kuntum bunga mekar 17 kuntum. Penggunaan aquades sebagai larutan peraga hanya mampu memekarka kuntum bunga sebanyak 14 kuntum (Tabel 5.).
Hal ini terjadi karena di dalam larutan peraga terdapat cadangan makanan yang berupa gula untuk bunga sedap malam, sehingga bunga mampu melakukan aktivitas metabolismenya untuk mendapatkan energi guna membantu dalam proses pemekaran kuntum bunga. Sesuai dengan penelitian yang dilakukan Tisnawati (2005), menyatakan bahwa penggunaan gula $4 \%$ dalam larutan perendam bunga sedap malam potong mampu meningkatkan jumlah kuncup mekar sedap malam potong. Selain itu Kurniawan, dkk (2008) juga melaporkan bahwa penggunaan gula 100 g.l $^{-1}$ mampu merangsang mekarnya kuncup bunga anggrek potong Dendrobium sonia.

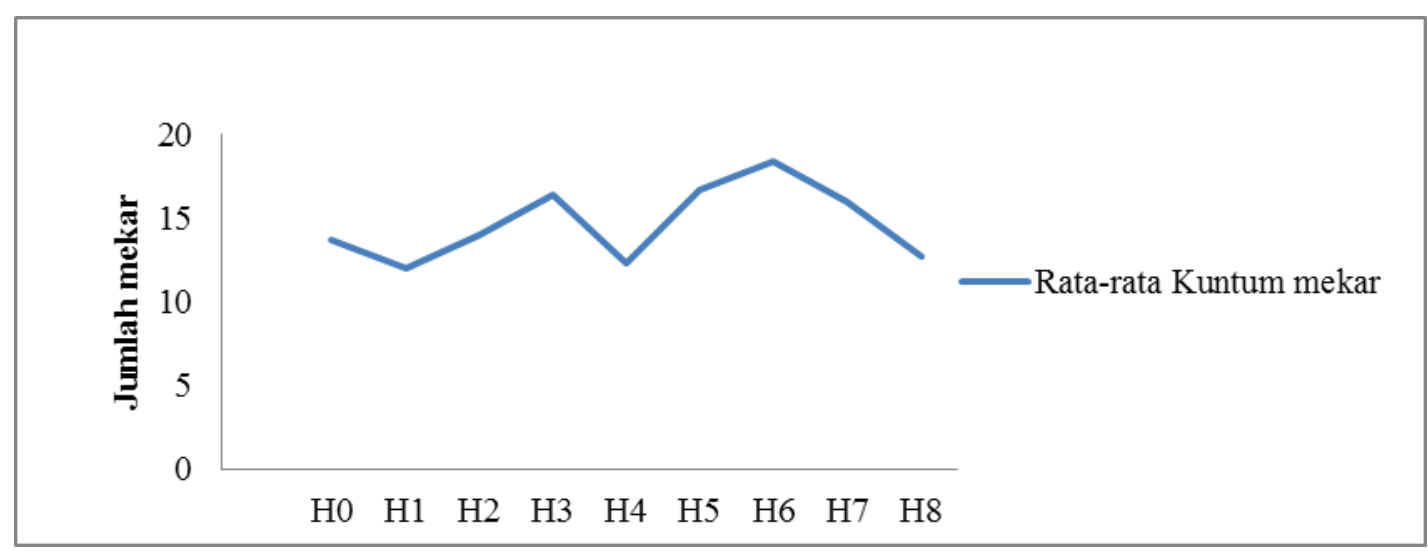

Gambar 3. Jumlah Kuntum Bunga Mekar Sedap Malam Selama Masa Peragaan

Dapat dilihat pada Gambar 3. bahwa tertinggi dan cenderung menunjukkan larutan peraga dengan penambahan tren yang menurun seiring dengan ekstrak daun sirih, lidah buaya, dan 5 tetes penambahan jumlah tetesan CMD. Perlu CMD dalam 1 liter larutan peraga mampu diketahui bahwa dalam proses pemekaran memekarkan kuntum bunga sedap malam bunga dapat dipengaruhi beberapa faktor 
yaitu selain adanya cadangan makanan berupa sukrosa atau gula, asam amino (protein) juga berperan dalam proses pemekaran bunga. Pada proses pemekaran bunga juga dibutuhkan banyak energi dan fosfor membantu dalam menyediakan energi dalam proses pemekaran bunga tersebut (Grant, 1999). Ekstrak lidah buaya mengandung asam amino esensial yang dapat dimanfaatkan oleh bunga sedap malam serta pada CMD sendiri terkandung nitrogen yang dapat membantu proses pembentukan asam amino pada sel tumbuhan dan fosfor yang membantu memberikan energi dalam proses pemekaran bunga. Kadar sodium yang tinggi pada larutan dapat menghambat serapan larutan peraga oleh bunga potong karena mengubah daya osmotik potensial air sehingga dapat membuat daun dan petal menjadi terbakar diakibatkan terakumulasinya sodium pada kuntum bunga paling ujung (L.B Ghast, 1997). Sehingga diduga sodium yang terkandung dalam CMD mampu menghambat proses pemekaran bunga sehingga dapat terlihat bahwa penambahan tetesan CMD cenderung menurunkan jumlah kuntum mekar bunga sedap malam selamaperagaan.

\section{SIMPULAN}

Pemberian ekstrak lidah buaya, ekstrak daun sirih, dan Concentrated Mineral Drops (CMD) pada larutan peraga mampu memperpanjang masa kesegaran bunga sedap malam selama lima hari peragaan dengan interval persentase kuntum bunga yang mengalami kelayuan sebanyak 12.29\% - 20.70\% (lebih rendah) dibandingkan dengan pemberian aquades saja (28.18\%). Larutan peraga yang terdiri dari ekstrak sirih, gula, dan asam sitrat lebih ekonomis dibandingkan dengan larutan lainnya karena pada hari ke-6 peragaan bunga masih menunjukkan kondisi fisik bunga cukup baik walaupun telah mengalami kelayuan sebanyak 56.33\%. Pemberian ekstrak lidah buaya, ekstrak daun sirih, dan Concentrated Mineral Drops (CMD) pada larutan peraga mampu mempengaruhi daya serap bunga secara sangat nyata dengan interval volume larutan peraga yang terserap yaitu sebanyak $44.17 \mathrm{ml}$ - 57.33 ml. Pemberian ekstrak lidah buaya, ekstrak daun sirih, dan Concentrated Mineral Drops (CMD) pada larutan peraga tidak mampu mempengaruhi jumlah kuntum bunga mekar pada bunga sedap malam selama peragaan. 


\section{DAFTAR PUSTAKA}

Kurniawan, A.A.; T. Wardiyati. \& E. Nihayati. (2008). Pengaruh Komposisi Larutan Perendam Dalam Memperpanjang Kesegaran Anggrek Potong Dendrobium. http://elib.ub.ac.id. [tanggal 1 Agustus 2011]

Alamendah. (2011). Mengenal Bunga Sedap Malam (Polianthes tuberosa). http:// alamendah. wordpress. com. [9 September 2011]

Anonimous. (1998). Environmental effects of Potassium. http:// www. lenntech. com/ periodic/elements/k.htm. [28 Maret 2012]

Anonimous, (2011). Sedap Malam. Wikipedia Bahasa Indonesia, ensiklopedia bebas. http:// id. wikipedia.org. [1 Agustus 2011]

Anonimous, (2010). Great Salt Lake, Utah, USA. http://tracemineral -sinergi. blogspot. com. [9 September 2011]

Anonimous, (2011). How to Make Aloe vera Gel. http:// www. wikihow. com/ Make-Aloe-VeraGel. [3 Oktober 2011]

Balai Penelitian Tanaman Hias. (2009). Ragam Bunga Sedap Malam di Indonesia. Warta Penelitian dan Pengembangan Pertanian Vol 31, No.5.

Badan Pusat Statistik. (2008). Produksi Tanaman Obat-obatan dan Hias 2004-2006.

Moeljanto, R. D. \& Mulyono. (2003). Khasiat dan Manfaat Daun sirih Obat Mujarab dari Masa ke Masa. Agromedia Pustaka. Jakarta.

Furnawanthi, Irni. (2003). Khasiat \& Manfaat Lidah Buaya: Si Tanaman Ajaib. Agromedia Pustaka. Jakarta

Grant, Bonnie. (1999). Phosphorus for Blooming Plants.http://www.ehow.com/info_7746516_p hosphorus-blooming-plants.html. [27 Maret 2012]

H. Hamman, J. (2008). Composition and Application of Aloe vera Leaf Gel. Molecules. 13, 1599 - 1616.

H. Jackson, R. (2011). Great Salt Lake. Utah History Encyclopedia. http:// historytogo. utah. gov. [11 September 2011]

Jurnalnet.com. (2005). Gel lidah buaya dapat digunakan sebagai bahan pengawet buah dan sayuran. http:// www. jurnalnet. com/ konten.php?nama $=$ BeritaUtama\&topik $=7 \& \mathrm{id}=$ 431. [3 Oktober 2011]
L.B. Ghast, K. (1997). Postharvest Handling of Fresh Cut Flowers and Plant Material. Horticulture \& Landscaping. Kansas State University

Revell Indonesia. (2008). Trace Mineral Drops. http://revellindo.com. [1 Agustus 2011]

S. Reid, Michael. Cut Flowers and Greens. Department of Environmental Horticulture. University of California, Davis, CA.http://www.ba.ars.usda.gov/hb66/148cutflo wers.pdf. [29 Maret 2012]

Sukma, D. \& Mardiansyah, G. (2007). Pengaruh Kalsium $\left(\mathrm{CaCl}_{2}\right)$ terhadap Kualitas Bunga Potong Anggrek Dendrobium 'Burana Strip'. Prosiding Simposium, Seminar dan Kongres IX PERAGI. Hortikultura 328 - 332.

Suyanti. (2002). Teknologi Pascapanen Bunga Sedap Malam. Jurnal Litbang Pertanian 21(1): 24-31.

Tisnawati. (2005). Teknik Memperpanjang Masa Simpan Bunga Potong Alpinia. Buletin Teknik Pertanian 10 (1): 40-42.

. (2005). Teknik Penggunaan Asam Benzoat dan Sodium Benzoat Untuk Memperpanjang Lama Peragaan Bunga Sedap Malam. Buletin Teknik Pertanian 10 (1): 9-11.

Waters, W.E. (1966). Toxicity of Certain Florida Waters to Cut Flowers. Florida State Horticultural Society. Sun City, Florida.

Hutabarat, P.W.K. (2007). Penggunaan Pewarna Makanan Cair Biru Untuk Pewarnaan Pada bunga Potong Sedap Malam (Polianthes tuberosa L.), Anyelir (Dianthus caryophyllus L.), Gladiol (Gladiolus grandiflorus), dan Mawar (Rosa hybrida L.). Makalah Seminar Departemen Agronomi dan Hortikultura, Fakultas Pertanian, IPB. Bogor.

Wullstein, B. (2010). Plant Life in Utah. Utah History Encyclopedia. http:// historytogo. utah.gov. [6 Juli 2011] 